\title{
Leadership of Xi Jinping behind Unstoppable Sustainable Economic Growth of China
}

\author{
Bablu Kumar Dhar ${ }^{1 *}$, Mahazan Mutalib ${ }^{2}$ \\ ${ }^{1}$ Faculty of Business and Entrepreneurship, Daffodil International University, Bangladesh \\ ${ }^{2}$ Faculty of Leadership and Management, Universiti Sains Islam Malaysia, Malaysia
}

\begin{tabular}{|c|c|}
\hline & ABSTRACT \\
\hline $\begin{array}{l}\text { Keywords: } \\
\text { Leadership, Xi Jinping, } \\
\text { Sustainable Economic } \\
\text { Growth, China }\end{array}$ & $\begin{array}{l}\text { Xi Jinping's new era of socialist economic thought, rooted in the great practice of China's } \\
\text { economic construction, systematically explains the issue of China's economic development } \\
\text { and reform, and clearly answers the important questions of how the economic situation is to } \\
\text { be judged, how to judge the development stage, how to determine the development goals, and } \\
\text { how to do economic work. Xi Jinping's new era of the socialist economy with Chinese }\end{array}$ \\
\hline Received & characteristics, system integrity, broad depth, logic and strict, each aspect of the discourse has \\
\hline 02 July 2020 & a creative and vital point of view, forward-looking strategic deployment and "four beams and \\
\hline $\begin{array}{l}\text { Received in revised form } \\
19 \text { July } 2020\end{array}$ & $\begin{array}{l}\text { eight pillars" of the key initiatives. Combining the in-depth study of Xi Jinping's new era } \\
\text { socialist ideology with Chinese characteristics and the spirit of the Party's 19th National }\end{array}$ \\
\hline Accepted & Congress, this paper tries to sort out Xi Jinping's new era socialist economic thought with \\
\hline 19 July 2020 & $\begin{array}{l}\text { Chinese characteristics from five aspects, such as direction theory, goal theory, epistemology, } \\
\text { strategy theory, and bottom-line theory. }\end{array}$ \\
\hline
\end{tabular}

*Correspondence:

drbablu.ba@diu.edu.bd

CCIKD Publishing

\section{Introduction}

China's economic development momentum is good, the internal mechanism of economic growth is continuously enhanced, and the unity of speed, quality and efficiency have basically been achieved. But it is also be soberly aware that no country in the world has sustained economic growth and will always maintain a high speed. China is no exception. The achievements are evident to all, but as the economic situation changes, some new contradictions and problems have emerged. For example, the reform of state-owned enterprises, the problem of enormous unemployment, polarization, corruption, financial risks, and environmental damage. These problems require us to attach great importance to find practical solutions as soon as possible (Jinping, 2018). 
At present, according to Chang-Liao (2016), Economy (2018) and Peters (2017), China's economic development focuses on the following aspects: First, strengthen real estate investment guidance, use economic and legal means to restrict the blind development of high-end commercial housing, and promote the construction of affordable housing. The second is to do an excellent job of tracking and monitoring the international and domestic economic situation and formulate a response plan promptly. The third is to strengthen macro-monitoring of industries such as automobiles and steel and prohibit low-level, repetitive construction and disorderly competition. It is necessary to stop the further spread of the overheating tendency of specific industries as soon as possible and to encourage reasonable factors in economic growth. What needs to be solved here is how to control the cent. It is necessary to regulate and guide the tendency of excessive investment growth in some industries and to take measures to solve the problem of intensified contradiction between supply and demand of some production factors. Fourth, various measures have been taken to solve the problem of power shortage in some areas. It is necessary to effectively strengthen water resources management, alleviate the shortage of water in some regions, and accelerate the reform of urban and agricultural water prices. Fifth, it continues to carry out in-depth clean government construction and anti-corruption work in the current and future period. China has started with the State Council and build a standard behavior mechanism to ensure that the government operates in a coordinated, fair, transparent, clean, and efficient manner. These measures show the determination of the Chinese leadership to strive to clear roadblocks at all levels and open up a smooth channel for economic growth.

Since the 18th National Congress of the Communist Party of China, the Party Central Committee with General Secretary Xi Jinping as the core brainstormed and profoundly summarized many theories and major development strategies for the current and future period of socialist economic development with Chinese characteristics, and gradually formed a new era of Xi Jinping Socialist economic thinking with Chinese characteristics (Bader, 2016; Wang \& Zeng, 2016). The theoretical implications it presents are as follows: at the stage of development, it is believed that China's economic development has entered a new normal, and it is a new stage of development that combines quality and quantity; on the question of "who" for economic development, it is clear that "people" The core position of "centering"; in the direction of economic development, the party's leadership in economic work is strengthened based on respecting the market allocation of resources; in solving the contradiction between supply and demand, a new idea of economic development with supply-side reform as the main line is proposed (Economy, 2018). On the relationship between the market and the government, the organic unity of the market's leading position and the government's macro-control is more clearly defined; in the direction of economic development, it insists on leading the modern economic system with new development concepts (Blackwill \& Campbell, 2016). This will further unite the will of the entire party and the people of the whole country and lay the ideological foundation for high-quality economic development. The 19th National Congress of the Communist Party of China established Xi Jinping's new era of socialism with Chinese characteristics as the guiding ideology that the Party must adhere to for a long time, and wrote it into the Party Constitution. Xi Jinping's new era socialist economic thought is the latest achievement of Marxism in China, contains the essence of dialectical materialism and historical materialism, embodies that General Secretary Xi Jinping has continuously enriched the development of Marxism, Mao Zedong Thought, Deng Xiaoping Theory, is a very valuable spiritual wealth of the Party and the state (Brown, 2017; Li, 2016; Rahman et al., 2018). 
The aim of the paper is to focus on the leadership strategies of Xi Jinping, the current most dynamic President of China and one of the greatest and influential leaders of the world. The study focuses on the current rapid and sustainable economic growth of China, the contribution of the current president in the unstoppable economic development of China, leadership style and characteristics of the current president and finally, the paper tries to sort out Xi Jinping's new era socialist economic thought with Chinese characteristics from five aspects, such as direction theory, goal theory, epistemology, strategy theory, and bottom line theory.

\section{Rapid Economic Develop of China}

The Chinese economy experienced extraordinary growth in the last few decades that projected the country to become the world's second-largest economy. China has become the world's manufacturing hub since the starting of the economic reforms in 1978, where industry and construction (secondary sector) signified the most significant portion of GDP. GDP development has averaged almost 10 percent a year, and more than 850 million people have been raised out of poverty. Growth has moderated in the face of structural restraints over the past few years, including declining returns to investment, slowing productivity, and diminishing labor force growth. The challenge going onward is to find new drivers of growth while addressing the social and environmental inheritances of China's previous development path (Dhar, 2020). Though, in recent years, China's transformation pushed the tertiary sector. In 2013, it converted the largest group of the GDP with a share of $46.1 \%$, while the secondary sector yet accounted for an ample $45.0 \%$ of the country's total output. In the meantime, the primary sector's weight in GDP has shriveled melodramatically since the country unlocked to the world (Economy, 2018).

China's speedy economic development surpassed the step of institutional expansion, and there are significant institutional and reform gaps that China desires to address to confirm sustainable and high-excellence growth path. Currently, China is the world's second-largest economy and an upper-middle-income country. China departed the financial crisis in dynamic ways, with GDP rising above $9 \%$, low inflation and an overall fiscal situation. Though, the policies executed during the crisis to substitute economic development exacerbated macroeconomic inequities of the country. Notably, the incentive program boosted investment, while consumption of households remained comparatively low. To challenge these inequalities, the new administration of President Xi Jinping and Premier Li Keqiang, beginning in 2012, has revealed economic actions aimed at endorsing a more balanced economic model at the expense of the once-sacred speedy economic growth (Wang \& Zeng, 2016). Table 1 indicates the recent rapid economic developments of China under the leadership of President Xi Jinping. The data of Table 1 have been collected from the report of the World Bank (2020). 
Table 1

Recent Economic Developments of China Under the Leadership of President Xi Jinping

\begin{tabular}{|c|c|c|c|c|c|}
\hline Indicators of Economic Development & 2015 & 2016 & 2017 & 2018 & 2019 \\
\hline Population (in million) & 1,375 & 1,383 & 1,390 & 1,395 & 1,400 \\
\hline GDP per capita (USD) & 7,945 & 8,134 & 8,858 & 9,916 & 10,212 \\
\hline Economic Growth (GDP, annual variation in \%) & 7.0 & 6.8 & 6.9 & 6.7 & 6.1 \\
\hline Annual Consumption (variation in \%) & 7.4 & 8.6 & 6.4 & 9.1 & - \\
\hline Annual Investment (variation in \%) & 7.0 & 6.8 & 5.2 & 4.9 & - \\
\hline Annual Industrial Production (variation in \%) & 6.1 & 6.0 & 6.6 & 6.2 & 5.7 \\
\hline Annual Retail Sales (variation in \%) & 10.7 & 10.4 & 10.3 & 9.0 & 8.1 \\
\hline Unemployment Rate & 4.1 & 4.0 & 3.9 & 3.8 & 3.6 \\
\hline Fiscal Balance (\% of GDP) & -3.4 & -3.8 & -3.7 & -4.1 & - \\
\hline Public Debt (\% of GDP) & 15.5 & 16.1 & 16.2 & 16.3 & - \\
\hline Annual Money (variation in \%) & 13.3 & 11.3 & 8.1 & 8.1 & 8.7 \\
\hline Annual Inflation Rate (CPI, variation in \%) & 1.4 & 2.0 & 1.6 & 2.1 & 2.9 \\
\hline Annual Inflation (PPI, variation in \%) & -5.2 & -1.3 & 6.3 & 3.5 & -0.3 \\
\hline Policy Interest Rate $(\%)$ & 4.30 & 4.30 & 4.30 & 4.31 & 4.15 \\
\hline Annual Stock Market (variation in \%) & 9.4 & -12.3 & 6.6 & -24.6 & 22.3 \\
\hline Exchange Rate (vs USD) & 6.49 & 6.95 & 6.51 & 6.88 & 6.96 \\
\hline Current Account ( $\%$ of GDP) & 2.8 & 1.8 & 1.6 & 0.4 & 1.2 \\
\hline Trade Balance (USD billion) & 594 & 510 & 420 & 351 & 422 \\
\hline Exports (USD billion) & 2,273 & 2,098 & 2,263 & 2,487 & 2,499 \\
\hline Imports (USD billion) & 1,680 & 1,588 & 1,844 & 2,136 & 2,077 \\
\hline Annual Exports (variation in \%) & -2.9 & -7.7 & 7.9 & 9.9 & 0.5 \\
\hline Annual Imports (variation in \%) & -14.3 & -5.5 & 16.1 & 15.8 & -2.8 \\
\hline International Reserves (USD) & 3,406 & 3,098 & 3,236 & 3,168 & 3,223 \\
\hline External Debt (\% of GDP) & 12.7 & 12.6 & 14.3 & 14.2 & - \\
\hline
\end{tabular}

\section{Leadership Style and Characteristics of Xi Jinping}

Since the 18th National Congress of the Communist Party of China, General Secretary Xi Jinping has demonstrated superb leadership skills and leadership art in many areas and fields such as reform, development, stability, internal affairs, diplomacy and national defense, governing the party and the country.

\section{People-friendly}

Taking the line of being close to the people and building an image of being close to the people are the most distinctive characteristics of General Secretary Xi's leadership style (Poh \& Li, 2017). Whether at the local level or to the central government, he tried his best to maintain close contact with the broad masses and kept in close contact with ordinary masses as much as possible.

\section{The Combination of Rigidity and Softness}

"Outer circle and inner side", outer softness and inner rigidity, softness with rigidity, and softness with rigidity are essential characteristics of Secretary Xi's acting style. On the one hand, his style is tight, upright, and quite iron-fisted; on the other hand, he has a sense of righteousness, sincerity, and straightforward and sincere temperament. On issues such as anti-corruption, the punishment of corruption, elimination of ugliness, and rectification of work style, they have always been selfless and merciless (Brady, 2017).

\section{Relaxed}

Talking about light topics, saying light words, and creating a relaxed atmosphere are the charms of smart leaders. In his words, General Secretary Xi often talks about personal experiences, interests and hobbies, talks about his heart, and talks about his heart. For example, he talked about his hobbies and hobbies and said that he likes reading (Rahman et al., 2018). 


\section{Dare to Take Responsibility}

In General Secretary Xi's series of speeches, the word "duty" is often seen, which has become a kind of leadership behavior that the General Secretary has repeatedly admired and practised. He repeatedly emphasized that "the responsibility to be taken must be assumed", "to be responsible, not to shirk, avoid, lie, tell the truth to the organization, be brave to take responsibility", and "dare to take responsibility in front of big and bad, Dare to stick to the principle" (Bader, 2016).

\section{Confidence}

Confidence and calmness, determination and perseverance are essential qualities and personality traits of General Secretary Xi's leadership style. The general secretary once said with deep feelings, "My growth and progress should be said to have started in Shaanxi during the seven or eight years, and the biggest gain has two points", one of which is "cultivated my self-confidence." For more than 20 years, the local governor has worked for a long time, and developed the calm and confident character of the general secretary. Since the 18th National Congress of the Communist Party of China, he has repeatedly called on the whole party to have road self-confidence, theoretical selfconfidence, institutional self-confidence, and to show self-confidence everywhere (Brown, 2017).

\section{Steady}

The general secretary's stability is in his atmosphere. He has repeatedly said, "Dare to be bold, and step to be stable"; "The direction must be accurate, and the driving must be stable"; Seeking progress in the middle, seeking stability in the stable; "Small fire burns warm water, constant fire constantly", and so on. These ideas and requirements have highlighted the word "stable", reflecting his steady leadership style and behavior characteristics. As a leader of a big country, he thinks deeply about issues, makes decisions, and plans far-reaching. He is based on the present, has a longterm perspective, and has a firm grasp of direction. This steady atmosphere stems from his heavy life experience, massive cultural knowledge and heavy practical accumulation (Brown \& BērziņaČerenkova, 2018).

\section{Pragmatic and Flexible}

Everything is based on reality. Seeking truth from facts is the living soul of Marxism and the living soul of General Secretary Xi's leadership style. According to Xi, "Let me understand what it means to be practical, what it means to seek truth from facts, what is the masses. This is something that will benefit me for life." He also said: "Many of the ideas of seeking truth from facts have sprouted from that time, so that now affects me every moment" (Brady, 2017).

From the leadership style and characteristics of General Secretary Xi, one can get a glimpse of his entire ruling style and characteristics, as well as new historical conditions. The party's ability to govern and its direction is a model and sample book for leading cadres at all levels to improve their ability to govern and lead.

\section{Analysing the Leadership of Xi Jinping from Different Aspects}

Based on the important speeches of General Secretary Xi Jinping, the study tried to point out some preliminary thoughts on the rich connotations and theoretical system of Xi Jinping's new era of socialist economic thought with Chinese characteristics, drawing on the combing and interpretation of General Secretary Xi Jinping's thoughts on economic construction. This paper tries to sort out 
Xi Jinping's new era socialist economic thought with Chinese characteristics from five aspects, such as direction theory, goal theory, epistemology, strategy theory and bottom-line theory.

\section{Direction Theory}

The direction is the ideal path to the goal. Party, government, military and civilian science, east and west in the north and south, the Party is leading everything, the Party is the direction, the overall situation. Socialism with Chinese characteristics is the only correct way to realize the great rejuvenation of the Chinese nation, which was opened by the Party's leaders and the people after a long period of exploration and practice, and can only be developed under the leadership of the Party.

General Secretary Xi Jinping pointed out that the Communist Party of China is the leading core of the cause of socialism with Chinese characteristics and is in the position of overall control and coordination of all parties. The Communist Party of China Party is the ruling party; economic work is the central work of the Party to govern the country, do an excellent job in economic work, the Party Central Committee must take overall responsibility for economic work, the implementation of all-round leadership. Strengthening the Party's centralized and unified leadership in economic work, and correctly handling the relationship between the Party and government are the most fundamental guarantees and relate to the direction of future economic work (Kostka \& Zhang, 2018). On this issue, the whole Party has a more unified understanding and a sound organizational mechanism. Since the 18th National Congress of the Communist Party of China, General Secretary $\mathrm{Xi}$ Jinping has personally served as the head of the Central Leading Group on Finance and Economics, presided over 16 meetings of the Central Leading Group on Finance and Economics, and has been working on the development of China's economy in all directions, constantly opening up new horizons (Takeuchi, 2019). After the 19th National Congress of the Communist Party of China, the Central Finance Committee was formally established, and General Secretary Xi Jinping served as the director of the Central Finance Committee, in order to strengthen the CPC Central Committee's centralized and unified leadership of significant work related to the overall work of the Party and the state, and strengthen decision-making and overall coordination responsibilities (Bougon, 2018).

$\mathrm{Xi}$ Jinping's new era of socialist economic thinking with Chinese characteristics, there is also an important content, is to adhere to the correct direction of reform. General Secretary Xi Jinping has repeatedly stressed that the purpose of promoting reform is to continuously promote the selfimprovement and development of the socialist system.

\section{Goal Theory}

The goal is the way forward, and after the goal is established, a series of strategies and efforts are pointed. Since the 18th National Congress of the CPC, the CPC Central Committee, with Comrade $\mathrm{Xi}$ Jinping as its core, has proposed the Chinese dream of the great rejuvenation of the Chinese nation, established the goal of "two hundred years", inherited and developed the goal of socialist modernization set by the leadership of Congress Party over the past generations, and consolidated the great power of the Chinese nation to build its dream (Blackwill \& Campbell, 2016).

The basic connotation of the Chinese dream is "the country is rich and strong, the nation is revitalized and the people are happy". In his many speeches and on many occasions, General Secretary Xi Jinping stressed the realization of the Chinese dream, and in a big way, the first must 
be the road of China, that is, the road of socialism with Chinese characteristics. The people of all ethnic groups throughout the country must strengthen their theoretical self-confidence, selfconfidence in the road, self-confidence in the system and their cultural self-confidence, and unswervingly forge ahead along the correct Path of China. Second, it must carry forward the Chinese spirit, that is, the national spirit with patriotism as its core, and the spirit of the times with reform and innovation as its core (Chang-Liao, 2016). The people of all ethnic groups throughout the country must carry forward the great national spirit and the spirit of the times, and constantly strengthen the spiritual ties of unity and unity, the spirit of self-improvement, and always move vigorously into the future. Third, China must be united, that is, the strength of the Chinese people of all ethnic groups. The people of all ethnic groups throughout the country must bear in mind their mission, think everywhere, make a strong effort to make, with the wisdom and strength of 1.3 billion people to gather invincible strength (Wang \& Zeng, 2016).

\section{Epistemology Theory}

The theory of the new normal of economic development is the scientific epistemology of the new stage of economy, only by deeply understanding, grasping and leading the new normal of economy can the Chinese not only maintain the stability of the war, not to engage in strong stimulus, but also actively act as a proactive and active policy to stabilize the economy, transformation and upgrading. After the goal of the Great Chinese Dream of the Great Rejuvenation of the Chinese nation has been established, in order to do all the work well, it must recognize the present situation and understand the current stage of development and historical orientation. The CPC Central Committee, with Comrade Xi Jinping as its core, reviewed the situation and comprehensively studied and judged, and put forward the new normal of economic development and the main contradictions of society, which can be summarized as the epistemology of Xi Jinping's new era of socialist economic thought with Chinese characteristics (Bougon, 2018).

With the deepening of the international financial crisis, some contradictions in the domestic economic development have been highlighted, the downward pressure on the economy has increased, and the growth rate has undergone a phased change. Against this background, in May 2014, General Secretary Xi Jinping visited Henan for the first time to propose the "New Normal", and then continued to develop and improve the understanding of the new normal of economic development. In a June 2015 study in Guizhou, General Secretary Xi Jinping stressed that adapting to, grasping and leading the new normal is the great logic of China's economic development in the current and future period. The Central Economic Work Conference at the end of 2016 stressed the need to adhere to the overall tone of the work of steady progress (Ross \& Bekkevold, 2016).

\section{Strategy Theory}

Great goals require great practice, and great practice requires a strategy that keeps pace with the times. The five development ideas put forward by the Fifth Plenary Session of the 18th Central Committee of the Communist Party of China and the high-quality development policy put forward by the 19th National Congress are the scientific strategies for achieving the goals. A correct understanding of China's current development environment, in-depth implementation of new development concepts, promotion of high-quality development, the construction of a modern economic system, etc., can be summarized as Xi Jinping's new era of socialist economic ideas with Chinese characteristics (Brown \& Bērziņa-Čerenkova, 2018). 


\section{Bottom Line Theory}

The Chinese dream of realizing the great rejuvenation of the Chinese nation is not plain sailing, it should be good at using the bottom-line thinking. To establish a sense of risk, to prevent financial risks, firmly grasp the bottom line of society. Everything is prepared from bad to good. The general secretary's remarks can be summed up as the bottom line of Xi Jinping's new era of socialist economic thinking with Chinese characteristics.

General Secretary Xi Jinping has repeatedly stressed that China is in the historical stage of moving into high-income countries in the middle-income trap, and that various risk contradictions should be superimposed, so as to enhance the consciousness of bottom-line thinking and prevent all kinds of major risks, including domestic economic, political and ideological risks, as well as international economic, political and military risks, and strive not to have major risks, and to be able to carry and live with major risks (Poh \& Li, 2017).

Moreover, Xi has a lot of discussion on safety awareness and bottom-line thinking. For example, the connotation and extension of Chinese national security are richer than at any time in history, the field of time and space is wider than at any time in history, internal and external factors are more complex than at any time in history, it must adhere to the overall national security concept, with the people's security as the purpose, political security as the fundamental, economic security as the basis, military, cultural and social security.

\section{Conclusions and Implications}

Xi Jinping's new era of socialist economic thought with Chinese characteristics is the crystallization of the collective wisdom of the whole Party in the process of leading the Party and the people in the process of socialist modernization, but the main founder is Comrade Xi Jinping. This brilliant thought based on the national conditions, looking at the world and leading the future has mainly been formed since the 18th National Congress of the Communist Party of China, but Comrade Xi Jinping's hard work and practice in his early years have been profound.

Xi Jinping's new era of socialist ideology with Chinese characteristics, system integrity, broad depth, strict logic, covering politics, economy, culture, society, ecology, diplomacy, military, Party building and other aspects, each field has a series of innovative and essential ideological points, with forward-looking and leading strategic deployment. Xi Jinping's new era of socialist economic thought, rooted in the great practice of China's economic construction, systematic interpretation of China's economic reform and development.

This socialist economic thought clearly answered china's economic situation, how to determine the stage of development, how to determine development goals, how to do economic work and other significant issues. Xi Jinpings's leadership model is the fundamental follow of the long-term sustainable development of China's economy. Moreover, this thought is the new era to promote China's high-quality economic development of the action guide, is the new era of socialist political economy, is the latest chapter of Marxist political economics in the 21st century. 


\section{References}

Bader, J. A. (2016). How Xi Jinping sees the world \& and why. Brookings Institution.

Blackwill, R. D., \& Campbell, K. M. (2016). Xi Jinping on the global stage: Chinese foreign policy under a powerful but exposed leader. Council on Foreign Relations Press.

Bougon, F. (2018). Inside the Mind of Xi Jinping. Oxford University Press.

Brady, A. M. (2017). Magic Weapons: China's political influence activities under Xi Jinping (Vol. 18). Washington, DC: Wilson Center.

Brown, K. (2017). The Powers of Xi Jinping. Asian Affairs, 48(1), 17-26.

Brown, K., \& Bērziņa-Čerenkova, U. A. (2018). Ideology in the era of xi jinping. Journal of Chinese Political Science, 23(3), 323-339.

Chang-Liao, N. C. (2016). China's new foreign policy under Xi Jinping. Asian Security, 12(2), 82-91.

Dhar, B. K. (2020). Impact of COVID-19 on Chinese Economy. Economic Affairs, 9(3/4), 23-26.

Economy, E. (2018). The third revolution: Xi Jinping and the new Chinese state. Oxford University Press.

Jinping, X. (2018). Congratulatory message of president Xi Jinping on the 35(th) Annual Meeting of the InterAction Council. International Understanding, (4), 2.

Kostka, G., \& Zhang, C. (2018). Tightening the grip: environmental governance under Xi Jinping. Environmental Politics, 27(5), 769-781.

Li, C. (2016). Chinese politics in the Xi Jinping era: Reassessing collective leadership. Brookings Institution Press.

Peters, M. A. (2017). The Chinese Dream: Xi Jinping thought on Socialism with Chinese characteristics for a new era. Educational Philosophy and Theory, 49(14), 1299-1304.

Poh, A., \& Li, M. (2017). A China in transition: The rhetoric and substance of Chinese foreign policy under Xi Jinping. Asian Security, 13(2), 84-97.

Rahman, M. Z., Kumar, N., Anusara, J., Chanthamith, B., \& Khatoon, H. (2018). The Rise of China: Dream of Xi Jinping. Research in Social Sciences, 1, 53-59.

Ross, R. S., \& Bekkevold, J. I. (2016). China in the era of Xi Jinping: Domestic and foreign policy challenges. Georgetown University Press.

Takeuchi, H. (2019). Domestic politics of Chinese foreign policy: where will Xi Jinping bring China? Asian Security, 15(2), 205213.

Wang, Z., \& Zeng, J. (2016). Xi Jinping: the game changer of Chinese elite politics? Contemporary Politics, 22(4), 469-486.

World Bank (2020). The World Bank Report; Country: China. Retrieved from https://www.worldbank.org/en/country/china/overview\#1 (Accessed: June 23). 